\title{
Lepisanthes ferruginea (Sapindaceae) - A new record for India from Andaman and Nicobar Islands
}

\author{
Joju P. Alappatt \\ Department of Environment and Forests, Forest Training Institute, Wimberlygunj, \\ Andaman and Nicobar Islands - 744206, India. \\ E-mail: jojualappatt@yahoo.com
}

\begin{abstract}
Lepisanthes ferruginea (Radlk.) Leenh. is reported as new record to the Flora of India from Andaman and Nicobar Islands. A brief description with illustration and photographs is provided for easy identification.
\end{abstract}

Keywords: Andaman and Nicobar Islands, India, Lepisanthes ferruginea, New Report, Sapindaceae

\section{Introduction}

Lepisanthes Blume is a widespread genus in the family Sapindaceae comprising about 24 species (Leenhouts, 1969) and distributed from Africa, Madagascar, Sri Lanka, India, China through Malesia to New Guinea and north-western Australia (Leenhouts, 1969; van Welzen, 1999). The genus is represented by five species in India (Pant, 2000), of which four species are reported from Andaman and Nicobar Islands so far (Pandey \& Diwakar, 2008; Murugan et al., 2016).

During floristic explorations in Nicobar group of islands, a few specimens belonging to the genus Lepisanthes were collected from Great Nicobar Island. On critical study, the specimens were identified as Lepisanthes ferruginea (Radlk.) Leenh. A thorough scrutiny of literature (Hiern, 1872; Sinha, 1999; Pant, 2000; Pandey \& Diwakar, 2008; Murugan et al., 2016.) revealed that this species was hitherto unrecorded from Andaman and Nicobar Islands and mainland India. Hence the present report forms an addition to the Flora of India. A brief description along with illustration and photographs (Figs. 1, 2) is provided to facilitate easy recognition of this species in the field.

Lepisanthes ferruginea (Radlk.) Leenh., Blumea 17: 69. 1969; Leenh. in Adema et al., Fl. Males., Ser. I, 11(3): 634. 1994; Welzen in T. Santisuk \& K. Larsen, Fl. Thailand 7(1): 213. 1999. Hebecoccus ferrugineus Radlk., Sitzungsber. Math.-Phys. Cl. Konigl. Bayer. Akad. Wiss. Munchen 8: 301. 1878; Backer \& Bakh.f., Fl. Java 2: 134. $1965 . \quad$ Figs. 1,2

Tree, to $15 \mathrm{~m}$ high; branchlets terete, greyish to yellowish brown, minutely hairy when young. Leaves paripinnate, alternate, 2 or 3-jugate; leaflets opposite to subopposite, oblong-ovate to oblong to lanceolate, 10-25 × 4-9 cm, base obtuse to acute, apex acute to acuminate, chartaceous, glabrous on both surfaces; midrib and lateral veins prominent, 8-10 pairs; petioles swollen at base, c. $5 \mathrm{~cm}$ long. Inflorescence terminal and upper axillary, c. $35 \mathrm{~cm}$ long, ferrugineous to fulvous-velvety, glabrescent. Flowers c. $6 \times 5 \mathrm{~mm}$. Sepals 5, free, green, fulvoussericeous outside, glabrous inside, margins glandular-ciliolate; outer sepals 2 , oblong-ovate, $c$. $3 \times 1.5 \mathrm{~mm}$; inner sepals 3 , broadly obovate, c. $3.5 \times$ $2.5 \mathrm{~mm}$. Petals 5, obovate-cuneate, slightly clawed, c. $3.5 \times 2 \mathrm{~mm}$, basal half densely appressed longhairy, margins except for the upper part ciliate, white; scale erect, slightly more than half as long as the petal, laterally partly adnate to the margins, free part deltoid to bilobed, densely ciliate; disk glabrous. Stamens slightly exserted; filaments c. $2.5 \mathrm{~mm}$ long, densely long-hairy; anthers ovate, apiculate. Ovary c. $1.5 \mathrm{~mm}$ long; style conical, c. $1 \mathrm{~mm}$ long; stigma faintly 3-lobed. Fruits globular, c. $2.5 \mathrm{~cm}$, slightly 3-lobed, mostly only one lobe developed, densely ferrugineous-velvety, orange to brown.

Flowering \& fruiting: November-February.

Habitat: Rare in inland evergreen forests growing at an elevation of $10-15 \mathrm{~m}$.

Distribution: Peninsular Malaysia, Indonesia (Java and Sumatra), Thailand and now in India.

Specimen examined: INDIA, Andaman and Nicobar Islands: Great Nicobar Island, NS Road, 3-4 km, 16.12.2011, Joju P. Alappatt 395 (PBL).

Note: Lepisanthes ferruginea (Radlk.) Leenh. shows some similarity with L. tetraphylla (Vahl) Radlk. however, from which it is differentiated by the 


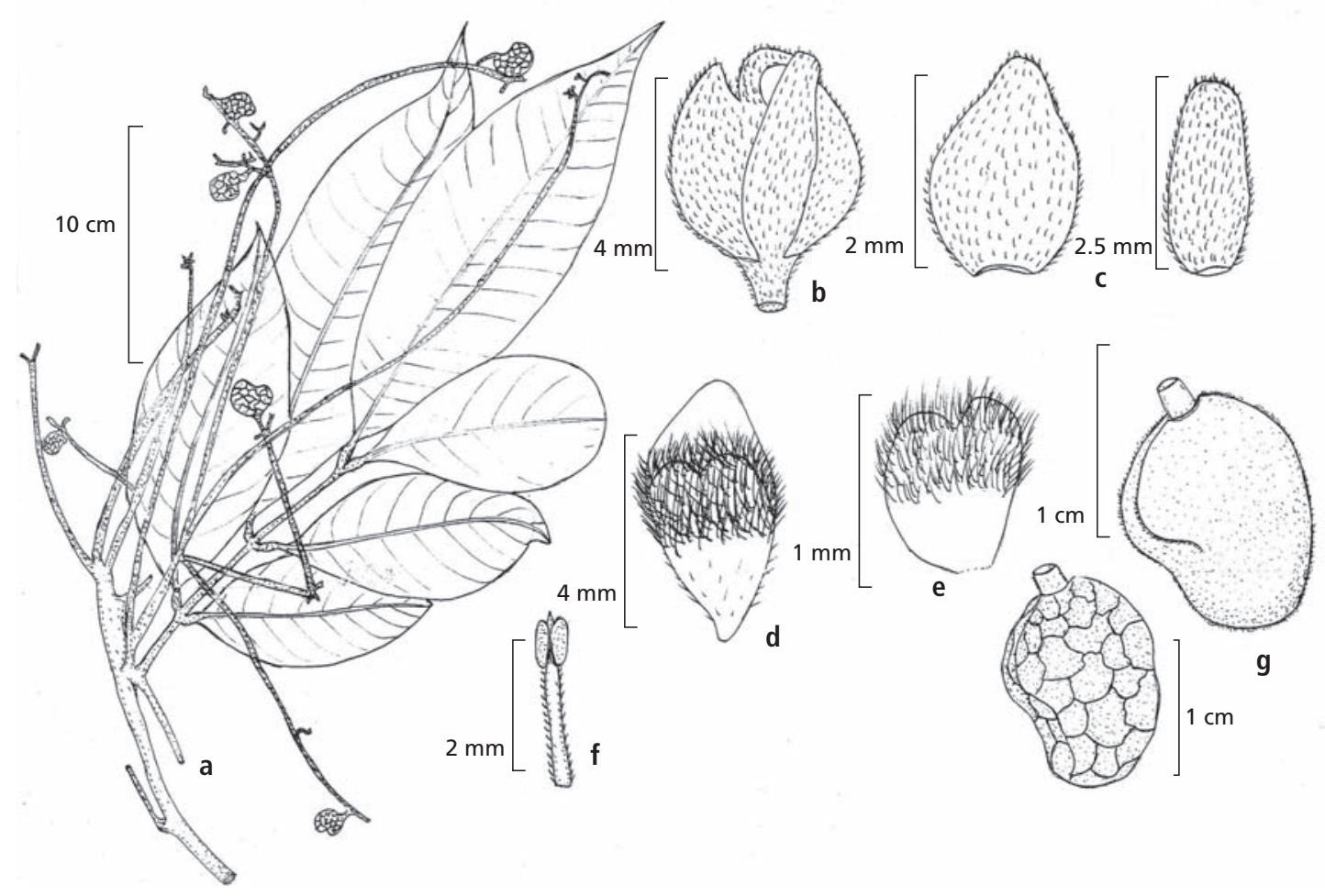

Fig. 1. Lepisanthes ferruginea (Radlk.) Leenh.: a. Fruiting-branch; b. Flower (male); c. Sepal (inner and outer); d. Petal; e. Petal scale; f. Stamen; g. Young fruit (fresh and dried) (Joju P. Alappatt 395, PBL).
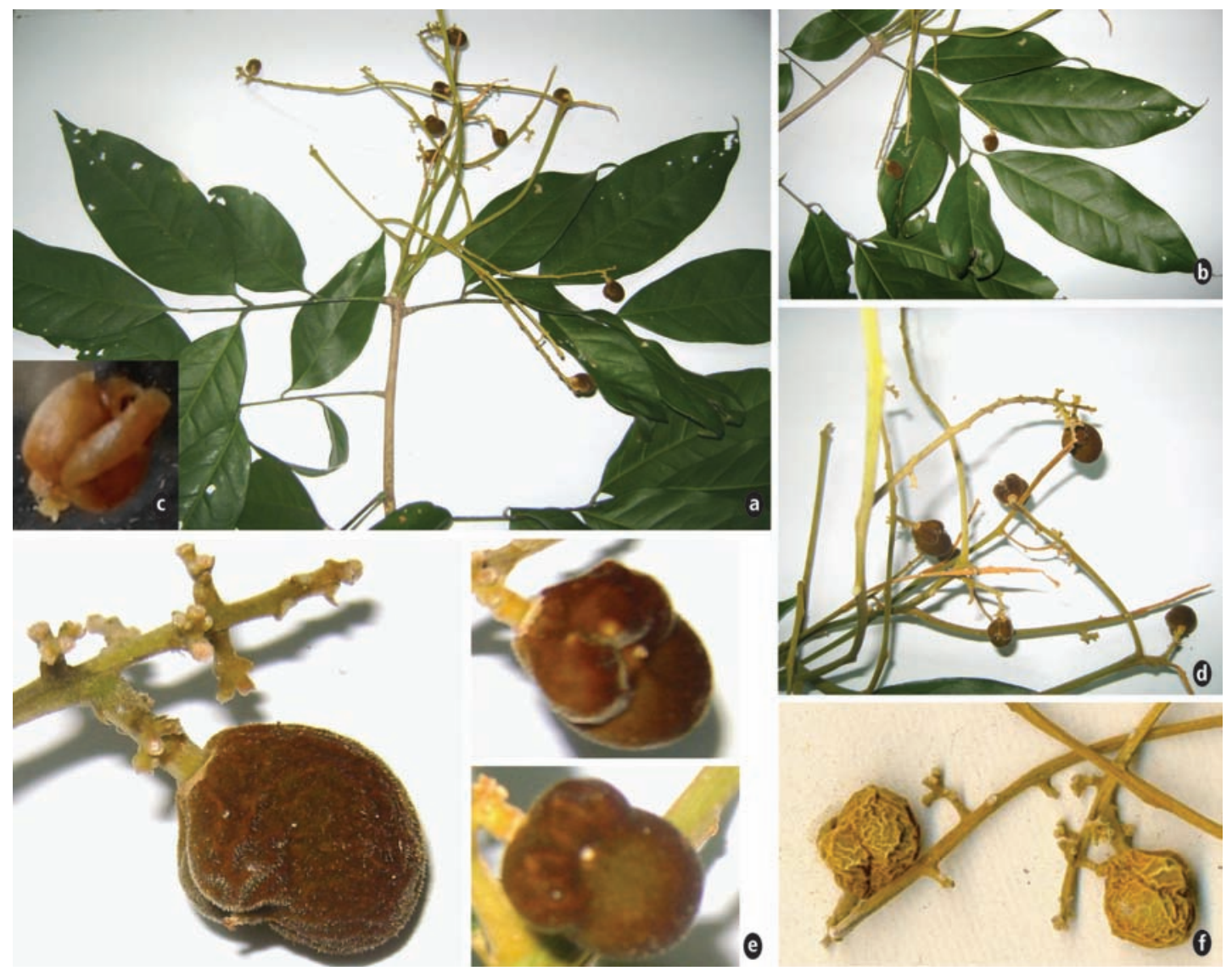

Fig. 2. Lepisanthes ferruginea (Radlk.) Leenh.: a. Fruiting-branch; b. Leaf; c. Flower (spirited); d. Fruits; e. Single fruit (young) enlarged; f. Dried fruit (young). 
large terminal and upper axillary inflorescence and fruits with the pericarp more or less strongly wrinkled when dry.

\section{Acknowledgements}

The author is grateful to Mr. M.S. Negi, IFS, PCCF, Department of Environment and Forests, Andaman and Nicobar Islands and Dr. Lal Ji Singh, Botanical Survey of India, Port Blair, for providing facilities and support; Dr. Frits Adema, Naturalis Biodiversity Center, The Netherlands, for confirming the identity of the specimen.

\section{Literature Cited}

Adema, F., Leenhouts, P.W. \& P.C. van Welzen 1994. Sapindaceae. In: Flora Malesiana Ser. I, Spermatophyta. Vol. 11(3). Rajksherbarium, Leiden. pp. 419-768.

Backer, C.A. \& R.C. Bakhuizen van den Brink Jr. 1965. Flora of Java. Vol. 2. Noordhoff, Netherlands.

Hajra, P.K., Rao, P.S.N. \& Mudgal, V. 1999. Flora of Andaman and Nicobar Islands (Ranunculaceae to Combretaceae). Vol. 1. Botanical Survey of India, Calcutta.

Hiern, W.P. 1872. Sapindaceae. In: Hooker, J.D. (ed.), The Flora of British India. Vol. 1. L. Reeve \& Co., London. pp. 668-699.
Leenhouts, P.W. 1969. A revision of Lepisanthes (Sapindaceae). Blumea 17(1): 33-91.

Murugan, C., Prabhu, S., Sathiyaseelan, R. \& R.P. Pandey 2016. A checklist of plants of Andaman and Nicobar Islands. (Edited by P. Singh \& W. Arisdason). ENVIS Centre on Floral Diversity, Botanical Survey of India, Howrah. Published on the Internethttp:/www.bsienvis.nic.in/database/ Checklist-of-Andaman-Nicobar-islands 24427. aspx (accessed on 6th September 2017).

Pandey, R.P. \& P.G. Diwakar 2008. An integrated checklist flora of Andaman and Nicobar Islands, India. J. Econ. Taxon. Bot. 32(2): 403-500.

Pant, P.C. 2000. Sapindaceae. In: Singh, N.P., Vohra, J.N., Hajra, P.K. \& D.K. Singh (eds.), Flora of India. Vol. 5 (Olacaceae-Connaraceae). Botanical Survey of India, Calcutta. pp. 343387.

Sinha, B.K. 1999. Flora of Great Nicobar Island. (Edited by P.K. Hajra \& P.S.N. Rao). Botanical Survey of India, Calcutta. pp. 195-198.

Welzen, P.C. van 1999. Sapindaceae. In: Santisuk, T. \& K. Larsen (eds.), Flora of Thailand. Vol. 7(1). The Forest Herbarium, Bangkok. pp. 169-250.

Received: 22.9.2017

Revised and Accepted: 25.11.2017 